\title{
How small island governments are responding to the development of energy technologies
}

\author{
M. J. de Vial \& E. P. Monkhouse \\ Island Analysis Limited, Guernsey
}

\begin{abstract}
With the backdrop of global concern about dwindling stocks of fossil fuels and climate change, small islands have additional pressures and challenges to adopt new energy technologies, particularly renewable energy.

As is well documented, islands are characterised by: insularity, a limited range of resources, small markets, specialisation of economies, diseconomies of scale, fragility of eco-systems and skill and labour constraints.

These characteristics create an over-reliance on imported fossil fuels, loss of economies of scale, and higher distribution costs. The motivation, therefore, to research, invest in and adopt alternative technologies is arguably heightened in island economies.

The benefits observed from examples of energy self-sufficient islands e.g. Samsø (Denmark), are driving greater investment by other islands and agencies into alternative solutions. The Pacific Islands in particular as a region is embracing alternative energy and has since 2007 , been receiving funding from the World Bank for a ten year programme.

Many small islands are well placed to trial such projects where funding is available, with: ready access to certain alternative energy sources e.g. tidal, wave, geothermal and solar energy; adaptable communities; and the ability to implement new technology and encourage rapid dissemination throughout the population. Additional benefits include encouraging on-island production of biofuels and supply of additional revenue to the economy.

Island Analysis will present a comparative study of energy policies and management in global island economies, drawing out the critical success factors and pointing to examples of leading edge practice.
\end{abstract}

Keywords: renewable energy, islands, strategic policies, economies, future, analysis. 


\section{Introduction}

With the backdrop of global concern about dwindling stocks of fossil fuels and climate change, small islands have additional pressures and challenges to adopt new energy technologies, particularly renewable energy. In some islands, energy demand is growing by $8 \%$ or more per year, requiring a doubling of the installed power plants every 12 years [1].

At the same time, relatively little effort is focused on the development of renewable energy sources (RES) and rational use of energy (RUE) in isolated areas like islands, rural areas, forest or coastal villages, mountain valleys etc. This is due to their geographical location and morphological characteristics, which are either isolated in terms of network infrastructure, i.e., electricity networks and transportation networks, or constitute ecologically protected areas, in which case infrastructure development interventions should comply to very specific requirements [2].

Yet there is arguably a huge opportunity for mainland economies to learn from the experience and successes of island based development of energy technology.

The remainder of this paper will present Island Analysis' comparative review of energy policies and management in global island economies, including:

- A profile of relevant island characteristics and the case for studying energy developments in this context

- An overview of current developments in energy technology within islands

- A reflection on trends in investment by the World Bank and other organisations in different technologies, over the last 10 years

- A review of the critical success factors and potential barriers associated with investment in new technologies

- Case studies where our analysis has revealed examples of how investment in energy technology interacts with broader policies to strengthen the island economy

- Conclusions on the learning points for islands and remote mainland communities.

\section{The island model}

As is well documented, islands are characterised by:

- Insularity

The Channel Islands, for example, benefit from their proximity to France, from which a cable supply of electricity provides up to $95 \%$ of the islands electricity when required. Other island communities do not have this option due to their remoteness from the mainland which not only reduces infrastructure options, but implies increased costs for shipping of fuel.

- A limited range and quantity of resources

○ Where there is, for example, the opportunity of tidal, wind and solar power, the infrastructure costs for a small population may be prohibitive, and the drive therefore to find new methods of exploitation is heightened. 
Access to fossil fuels, hydropower, geothermal energy etc even where available will by definition be limited by small land mass and environmental concerns.

- Small markets / diseconomies of scale

- The island populations encompassed in this review vary from only a couple of thousand to over half a million, but in some cases populations are smaller than a mainland town where one would not expect to find dedicated investment in new energy technologies.

- Specialization of economies

- Most island economies are dominated by either tourism, agriculture or the finance sector, placing different demands and constraints on both the energy required, and acceptability of technologies to the community.

- Fragility of eco-systems

- Following on from above, an island whose life-blood relies on tourism may be resistant to certain types of waste-to-energy plants, for example. But the global threat to islands is recognized as climate variability and change, brought into sharp focus by the Maldives government, who have pledged to become carbon neutral in ten years.

- Skill and labour constraints

- Islands are invariably resource constrained by both numbers of people and skill-sets, but have to balance the importation of expertise and labour with land-use, demands on infrastructure and quality of life.

This creates an over-reliance on imported fossil fuels and higher distribution costs. The motivation, therefore, to research, invest in and adopt alternative technologies is arguably heightened in island economies.

The benefits observed from examples of energy self-sufficient islands e.g. Samsø (Denmark), are driving greater investment by other islands and counties. The Pacific Islands in particular is a region embracing alternative energy and has been receiving funding from the World Bank since 2007, for a ten year programme.

In May 2010, technology students from Masdar Institute of Science and Technology (MIST) learned about self-sufficiency when they visited primitive villages on the island of Borneo, where water and solar power are alternated depending on weather conditions. The students were "inspired" to apply the learning back in their city setting [3].

Islands are well placed to trial such projects where funding is available, with ready access to certain alternative energy sources e.g. tidal, wave, geothermal and solar energy; adaptable communities; and the ability to implement new technology and encourage rapid dissemination throughout the population. Additional benefits include encouraging on-island production of biofuels to provide additional revenue to the economy. For those islands that have connectivity and/or close proximity to the mainland, there is the potential to sell energy via the mainland electricity grid. This opportunity is already being exploited by Samsø [4], and noted as a viable income source by a range of others such as Prince Edward Island [5], Tasmania [6] and Alderney [7]. 


\section{Current developments in energy technology within islands}

The awareness of islands' vulnerability to fluctuating oil prices has been highlighted frequently over the last 10 years, in island economic and strategic plans $[5,6]$. However, in recent years, high dependence on imported fuel sources has refreshed and promoted interest in the economic benefits of investment in alternative and renewable energy sources.

On Earth Day in 2001, Ministers and delegates from Small Island States announced their commitment to Renewable Energy and Global Sustainable Energy. It is acknowledged that although islands and small island nations are only responsible for a small percentage of global emissions, they are also recognised as amongst the most vulnerable to the effects of climate change. At the time a quoted figure of up to $12 \%$ [8] of island budgets was reported by the chair of AOSIS (Alliance of Small Island States) used for electricity generation by fossil fuels; since that time the proportion of GDP spent on import of oil has been reported as high as between 25 and $50 \%$ [9, 10].

- "The cost of energy is perhaps the singly most important factor affecting all aspects of the economy." Government of Barbados, 2006 [11]

- "These trends pose risks for us as well - but they also create opportunities - to become a net exporter of green energy." PEI Economic Strategy, 2008 [5]

It is also true that in the majority of islands, energy demand is consistently increasing rather than decreasing. For example, St Vincent and the Grenadines (SVG) experienced increased consumption from 64,840 toe (tonnes of oil equivalent) in 2002 to 91,000 toe in 2008 , an increase of $140 \%$ in volume. This represented a total import value rising from EC\$38m to EC\$150m [12], or 17\% of the country's GDP being used to pay for fossil fuels imports in 2008 (peaking due to extreme prices of US\$147 per barrel). Yet an assessment presented by the Multi-Sector Energy Stakeholder Consultation, indicates that the islands have the natural renewable resources to generate $100 \%$ of its electricity [13].

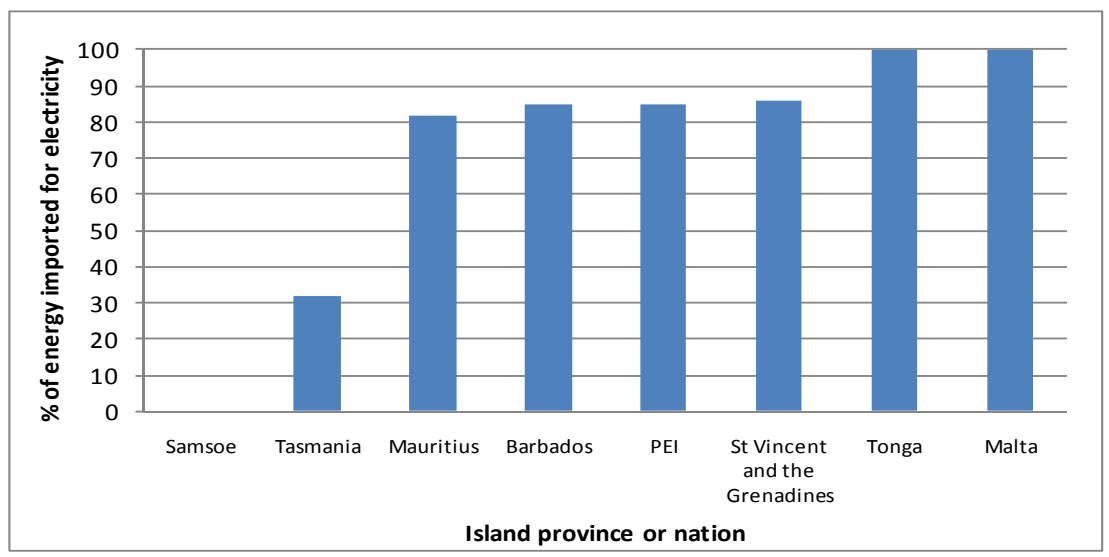

Figure 1: $\quad$ Proportions of energy imported for electricity generation (2008/9). 


\section{Investment trends in energy efficiency and renewable energy technology over the last 10 years}

\subsection{Worldwide}

The World Bank Group announced last year that their financing of renewable energy and energy efficiency projects in developing countries has risen by almost $25 \%$ to reach $\$ 3.3 \mathrm{bn}$ in the last fiscal year, total such commitments at financial y.e. June 30, 2009 represented more than $40 \%$ of total energy lending [14]. In addition there are other organisations covered under the umbrella of the World Bank Group that have significantly invested in renewable energy across the globe.

The International Finance Corporation (part of the World Bank Group) is regarded as a leader in supporting renewable energy finance in emerging markets. $70 \%$ of the financing (both in terms of number of projects and value) that it supported in the financial year of 2010 was in the area of renewable energy (Table 1). During the period FY 2009-2011 there has been a commitment of a further $\$ 3$ billion in financing for renewable energy and energy efficiency projects, in addition to over $\$ 2.3$ billion already invested since 2005 .

Table 1: World Bank Group lending for renewable energy and energy efficiency [14].

\begin{tabular}{|c|c|c|c|c|c|c|}
\hline US\$ Millions & FY05 & FY06 & FY07 & FY08 & FY09 & $\begin{array}{c}\text { Total } \\
\text { FY05- } \\
\text { FY09 }\end{array}$ \\
\hline $\begin{array}{c}\text { New Renewable \& } \\
\text { Energy Efficiency }\end{array}$ & 463 & 1,105 & 682 & 1,665 & 3,128 & 7,043 \\
\hline Large Hydro & 538 & 250 & 751 & 1,007 & 177 & 2,724 \\
\hline $\begin{array}{c}\text { New RE and EE } \\
\text { (Bonn Commitment) }\end{array}$ & 251 & 301 & 361 & 433 & 520 & 1,866 \\
\hline
\end{tabular}

\subsection{East Asia and the Pacific}

The majority of World Bank specific support for "renewable energy projects", related to islands has been located in the East Asia and Pacific region. In the last 10 years 13 projects have been in Indonesia and the Philippines. The Pacific Islands including Papua New Guinea, Solomon Islands, Fiji, Vanuatu and the Republic of the Marshall Islands in particular as a region of small island states, are embracing alternative energy which has been supported by the World Bank since 2007 , on a ten year programme [15]. 


\subsection{South Asia}

In South Asia, funding was received for seven projects from the World Bank, mainly based in Sri Lanka, with the majority of renewable energy projects exploiting hydro-power. The Asia Sustainable and Alternative Technology Program (ASTAE) [16], evaluates the current and future potential for renewable, providing advice to the World Bank and Global Environment Facility (GEF) investments. Islands and island nations currently covered by ASTAE include Tonga, Solomon Islands, Fiji, Indonesia, Papua New Guinea, Philippines, Singapore and Timor Leste.

\subsection{Caribbean}

There is a significant amount of investment in the creation of policies, strategies and regulation that is increasingly incorporating the development and efficiency of renewable energy technology. Financial assistance is often provided by alternative sources; for example the European Union Energy Initiative (EUEI) which is supporting the Caribbean Sustainable Energy Program (CSEP), currently being implemented in seven Eastern Caribbean States: Antigua and Barbuda, the Bahamas, Grenada, St Lucia, Dominica, St Vincent and the Grenadines, and St Kitts and Nevis (Barbados is an observer country). This is being implemented by the Department of Sustainable Development (DSD) within the General Secretariat of the Organization of American States (GS/OAS), in addition to several other organisations including the CARICOM Secretariat, REEEP (Renewable Energy and Energy Efficiency Partnership) and CARILEC (Caribbean Energy Utility Services Corporation) [17].

It is estimated that $200 \mathrm{MW}$ of renewable energy projects between the seven project countries will be put into action within 10 years of the conclusion of the project. In addition estimates of $15 \%$ reduction in demand are envisaged over that time frame due to the implementation of these renewable energy resources, subsequently also helping to reduce carbon emissions. One of the successful outputs from this is an Energy Action Plan, and a National Energy Policy for St Vincent and the Grenadines, achieved by updating the previous plans put forward by the local Government, who have been assisted by the German Agency for Technical Cooperation (GTZ) in the Caribbean Renewable Energy Development Program since 2005 [18].

The International Development Bank has also invested in the Caribbean. One such beneficiary, the Bahamas, is currently drafting their National Energy Policy. IDB signed agreements with the Government of Bahamas (March 2009) [19] to contribute towards the cost of the following two projects: 'Strengthening the Energy Sector in The Bahamas', and 'Promoting sustainable energy in The Bahamas'. The aim is an overall reduction in reliance on fossil fuels, with further objectives to diversify the mix of energy production, improve security and reduce emissions. 
As an indicator to the targets that the islands have set (Table 2), all EU countries and islands have Energy or Climate Change policies within which the directives have requested that all members must also have long term Renewable Energy Policy and Energy Efficiency Action plans. The target set for these EU countries is $20 \%$ by 2020 for the contribution of renewable energy to the total supply, in addition to a $9 \%$ reduction in end user consumption. Australia also has the same target for renewable energy supply.

Table 2: $\quad$ Targeted renewable energy supply figures by islands.

\begin{tabular}{|c|c|c|}
\hline Island & Renewable energy target (main grid) & Year \\
\hline Malta & $10 \%$ & 2020 \\
\hline Barbados & $30 \%$ & 2012 \\
\hline Prince Edward Island & $30 \%$ & 2013 \\
\hline Tonga & $50 \%$ & 2013 \\
\hline St Vincent and the Grenadines & $60 \%$ & 2020 \\
\hline Tuvalu & $100 \%$ & 2020 \\
\hline
\end{tabular}

\section{Case Study Islands with integrated energy policies}

\subsection{St Vincent and the Grenadines}

Future plans, in line with the Energy Action Plan for St. Vincent and the Grenadines 2010(EAPSVG) [20] are to promote and increase use of RET and RES. As of 2008, 2\% of total energy was renewable energy, however this excludes biomass, charcoal and solar thermal. In St Vincent, 5.6MW is consistently contributed by hydropower, however the requirements are increasing. In 1998 this 5.6MW of hydropower was a fifth of contributing power to the electrical grid; by 2007 this was less than 14\% (demand increased from $14 \mathrm{MW}$ to $20 \mathrm{MW}$ ). There were still diesel fuel generators being installed in 2007 to cope with the rising demand in the other islands of St Vincent and the Grenadines. Further hydro plants are planned, after successful feasibility studies have indicated that there is potential for development of new sites in addition to expansion of the current South Rivers Plant. Solar panels, imported from Barbados, are not widely utilised at present. Potential sites for wind power have been identified and public/private partnerships between the local energy provider (VINLEC) has been considered. Installation of two pilot grid-connected solar photo voltaic systems is to be looked into by VINLEC (St Vincent Electricity Services Ltd).

Biomass as an alternative is not sustainable at present, given that the current municipal waste on the island is not of high enough quality for immediate usage in the biogas technology plant. A dedicated energy crop would be required as a 
source, which is potentially viable if currently unused agricultural land was to be put back into use and by a change in agricultural markets (EAPSVG [21]).

\subsection{Tonga}

When Tonga was assessed in 2000, imported petroleum products accounted for $75 \%$ of the primary energy supply, with the further $25 \%$ arising from biomass and solar PV panels located off grid. Grid supplied electricity (98\% of electricity used in Tonga) is generated totally from imported diesel (TERM, [21]).

In 2010, ASTAE [22] reviewed the current state of the Tongan Electricity supply and forecast for the future. The resultant figures for electricity demand by 2020 indicated growth of between $3.5 \%$ and 5.5\%. Only five of Tonga's 52 inhabited islands have an electrical grid system. The majority of the remaining households obtain electricity through small individual diesel generator sets and solar panels with battery back-up. Most of these solar home based systems were installed with funding provided by aid agencies.

The Tonga Energy Road Map (TERM) [21] sets the vision for Tonga for the next 10 years to transform the energy sector on the islands. One of the key aims is to diversify the energy supply, progressing towards renewable energy with a target of achieving 50\% grid based electricity supply by 2013 . Technologies under consideration to achieve this are; landfill gas development, wind turbines without storage, coconut oil, solar PV without storage, and solar PV/wind turbines with storage.

\subsection{Prince Edward Island Energy Strategy}

Currently Prince Edward Island (PEI) is dependent on imported energy sources. As at 2009 , oil accounted for $76 \%$ of PEI total energy supply (46\% transport and $30 \%$ heating petroleum based fuels), with $10 \%$ biomass (fuel wood, sawmill residue and municipal waste), and $14 \%$ electricity.

For the future, as determined by the Prince Edward Island Energy Strategy [23] the vision is by 2013 for the energy supply to consist of: $4 \%$ renewable electricity, $10 \%$ energy efficiency (wind power), $50 \%$ petroleum products, $15 \%$ biomass, 7\% imported and oil fired electricity, and 5\% liquid biofuels. Renewable and non-petroleum based fuels are targeted to increase again by 2018 to $20 \%$ energy efficiency, $3 \%$ renewable, $20 \%$ biomass and $10 \%$ liquid biofuels.

The Government of PEI developed Atlantic Canada's first utility grade wind farm in 2001, since then the PEI Energy Corporation has expanded the first site and developed a further site resulting in running a $40.56 \mathrm{MW}$ wind power system. The Premier has indicated the intention to expand up to $500 \mathrm{MW}$ of wind energy capacity: "The Provincial Government will double its renewable energy portfolio from $15 \%$ to $30 \%$ by 2013." [23] This will require $\$ 1$ billion to develop the system but is forecast to bring in economic benefits of approximately $\$ 40$ million per annum to the economy (Prince Edward Island [24]). 


\subsection{Mauritius}

The current Mauritius plan is focused on high tech, low carbon renewable energy. In past years, schemes to introduce and promote usage of solar water heaters, have been very successful and have resulted in a grant being reinstated at Rs 10,000 in collaboration with commercial banks. 'Feed in' tariffs from small IPPs are also being purchased by the electricity board. Current work on a hydroturbine ( $2 \mathrm{GWh}$ per year) and installation of 5 wind turbines on nearby Rodrigues are some of the steps that are being taken, in addition to negotiations for a new wind farm, to secure renewable energy for the future of Mauritius [25, 26].

\subsection{Tasmania}

Ten years ago, Tasmania was reliant on imported oil for fuel and rainfall for the hydroelectric systems in place. Now, the electricity supply is more stable, composed of wind farms, hydroelectric, a gas pipeline from Australia across Bass Strait, and also the Basslink which gives access to up to 470MW of electricity supply which can be imported from the central Australian national electricity grid.

In the future, as part of the Tasmania Innovation Strategy [6], it is looking to build more renewable projects, with six onshore wind power project planned. Marine energy, due to the strong currents off the Western coast of Tasmania and Western Bass Straits in particular is an area looked to for future development, in addition to off-shore wind generation due to its location in the Roaring Forties (prevailing wind corridor). Bio-energy projects are also being assessed for viability in Tasmania. These primarily concentrate on production of methane from anaerobic digestion of waste from food processing facilities.

Geothermal exploration has been undertaken in Tasmania to determine the capacity for production. Overall it is looking promising for the future, with potential targets indicated close to the existing electricity grid, therefore increasing the attraction of this method of generation.

\section{Review of critical success factors and potential barriers associated with investment in new technologies}

\subsection{Community involvement}

In the work of the Integration of Renewable Energy Technologies in Rural Insular Areas Project [1], the report notes that a key success factor is positive engagement of the public through participative strategies on all aspects of the initiative - organizational, managerial and financial. That positive engagement is highly feasible in an island community, where politicians, civil servants and suppliers can be, and are expected to be, in direct communication with the public. The report describes a typical island context as an "open-minded culture conducive to novelty". The report goes on to highlight that successful sustainable energy solutions also require a mix of legal, regulatory, financial, 
communication and training measures, and again it is relatively feasible to profile and study the supporting sectors in a closed economy.

Samsø [4] is a prime example of a successful renewable island, local investors raised $80 \%$ of the capital for the $€ 50$ million for the energy system without any direct subsidy from the Danish government. A national programme which subsidised installation of systems for biomass heating, solar panels and heat pumps resulted in households switching to the alternatives. By 2005, the renewable energy contribution had risen to over $100 \%$ resulting in the surplus being exported as a commodity off island to mainland Denmark. This is a prime example of community involvement.

\subsection{Government assistance and subsidies}

Tasmania has been hampered slightly by the Australian Government's decision to postpone the Emissions Trading Scheme that was to be introduced to 2013 [27], which has resulted in carbon emissions not being included into the market price and therefore increasing the difficulty in raising capital investment for renewable energy.

Incentives that are offered by governments to individuals in the different islands are very similar, for example: Mauritius offer a subsidy of Rs 5,000 per unit of solar water heater installed in households; Tasmania - home solar power rebate - Aurora energy will rebate customers with a 'feed in' tariff for home solar power back into the system; Malta - Solar water heater installation, rebate of $20 \%$ with a maximum grant of $€ 232.94$ and other grants include microwind systems ( $25 \%$ to a maximum grant of $€ 232.94)$ and solar PV systems (min. size of $1 \mathrm{KW}+/-5 \%$ ) to a maximum grant of $€ 2329$.

Other areas noted to help increase uptake of RES and technologies include: conditional exemptions such as waiving of import duty payable on renewable energy systems; governmental support for installation of renewable energy technologies through grants, loans, tax and financial incentives; investigating taxation systems for cars based on $\mathrm{CO}_{2}$ emissions rather than engine capacity, and facilitating the implementation in the use of alternative fuels such as ethanol and biodiesel in land transport.

\subsection{Physical and environmental barriers}

Barriers include the natural features and the attraction of being an island that promote it being utilised for carbon free technology, (especially marine and wind based technology) can also constrain development. For example the following factors need to be considered: areas of scientific interest, shipping lanes and routes, protected areas of conservation, and significant sites for marine wildlife. In addition, many islands rely on tourism as their main sector contributing to the economy and visibility of energy developments is another factor for islands to consider when investing in different types of technology. 


\section{Conclusions on the learning points for islands and remote mainland communities}

The majority of islands have realised that security of energy resources and the ability to lessen the effect of any market volatility in energy prices is an intrinsic part of maintaining a stable and more profitable economy. Investment in energy, for on-island needs and/or as a commodity for export, is fast becoming a key component of economic strategies. Additional benefits include:

- economic diversification,

- income and jobs,

- compliance with carbon emissions reduction agreements.

Energy policies produced in the last five years, across a wide variety of world-wide islands are largely based around four main criteria:

- To secure a reliable energy supply for the future through the development of both renewable and non-renewable resources

- To diversify the energy profile of the island to reduce exposure to importation

- To enhance and advance the social and economic development of the island

- To reduce detrimental effects of energy production and protect the environment (if viable, by preferentially using low carbon or carbon neutral technologies).

The latter point has resulted in a determination by many small islands to set an example to other larger countries and nations. The stimulus for this is intertwined with the emissions reductions sought by the talks organised by the UNFCCC (United Nations Framework Convention on Climate Change).

AOSIS has been shown support at the climate talks in Cancun by the World Bank (The World Bank Press Release [9, 10]). In addition to their stance on increasing the targets that should be adhered to, they have pledged to lead by example and are determined to head into a time of renewable energy and efficiency. The signed memorandum of understanding between AOSIS, the World Bank and Danish Government calls for an introduction of renewable and energy efficiency into the island states with a US\$14.5m stimulus from the Danish Government.

\section{References}

[1] RERINA Project: Integration of Renewable Energy Technologies in Rural Insular Areas: State-of-the Art and Practice on SEC Development (D2.3.v2) April 2006 www.rerina.net

[2] World Wildlife Foundation, www.wwf.panda.org

[3] www.gulfnews.com, Article: "Borneo villagers inspire tech-savvy students: Trip gives Masdar pupils chance to use knowledge in sustainable energy". Published: May 9, 2010

[4] Jorgensen, P.J. Hermansen S., Johnsen, A., Nielsen, J.P., Jantzen, J., Lundén, M. Samsø - a Renewable Energy Island - 10 years of Development and Evaluation. PlanEnergi and Samsø Energy Academy 2007

[5] Prince Edward Island Economic Strategy - Island Prosperity - A Focus for change, Prince Edward Island Government 2008 
[6] Tasmania Innovation Strategy, Tasmanian Government 2010

[7] Alderney Renewable Energy, http://www.are.gb.com/

[8] Roper, T. Presentation: http://www.gseii.org/PDF/PPA2-Aug06-Final.pdf

[9] World Bank Press Release http://beta.worldbank.org/climatechange/content /small-island-states-get-boost-moving-renewable-energy

[10] Remarks by Helen Clark, UNDP Administrator Press Release, 08 Dec 2010

[11] Economic and Financial Policies of the Government of Barbados 2006, Government of Barbados

[12] Energy Action Plan for St. Vincent and the Grenadines 2009,

[13] Thomas Scheutzlich, Overview of Draft Energy Action Plan, CPEDP/GTZ, SVG, Multi-Sector Energy Stakeholder Consultation, 2009 http://www.sepa-americas.net/eventos_detalle.php?ID=20

[14] World Bank Press Release, http://beta.worldbank.org/news/renewableenergy-energy-efficiency-financing-world-bank-group-hits-all-time-high

[15] World Bank Sustainable Energy Finance Project P098423, http://web.worldbank.org/external/projects/main?pagePK=64312881\&piPK $=64302848 \&$ theSite $\mathrm{PK}=40941 \&$ Projectid $=\mathrm{P} 098423$

[16] ASTAE website, web.worldbank.org

[17] Organisation of American States (OAS), SEPA, Department of Sustainable Development http://www.sepa-americas.net/proyectos_detalle.php?ID $=6$

[18] OAS, SEPA, Dept of Sustainable Development, SVG http://www.sepaamericas.net/proyectos_detalle_pais.php? ID $=6 \&$ IdPais $=34$

[19] http://www.bahamas.gov.bs/bahamasweb2/home.nsf/vPrint/4FF5149A52B 5D47F8525761D005B4053

[20] Energy Action Plan for St. Vincent and the Grenadines, St. Vincent and the Grenadines Government, January 2010

[21] Tonga Energy Road Map completes plan to transform energy sectorhttp://www.tonga-energy.to/?p=1009, April 20, 2010

[22] ASTAE Report, Tonga Electric Supply System Load Forecast, World Bank, March 2010

[23] Prince Edward Island Energy Strategy 2009, Prince Edward Island Government

[24] Prince Edward Island, Island Wind Energy - Securing our Future: The 10 Point Plan, October 2008

[25] Mauritius Budget Speech 2010, The Government of Mauritius

[26] Mauritius Budget Speech 2011, The Government of Mauritius

[27] RSC, Australian emissions trading scheme on hold, 29/04/10 http://www.rsc.org/chemistryworld/News/2010/April/29041002.asp 